\title{
The Recognition and Behavior Management of Students With Talented and Gifted in an Inclusive Education Environment*
}

\author{
Osman Sabanc1 ${ }^{1}$, Safiye Sarıcı Bulut ${ }^{2}$ \\ ${ }^{1}$ Department of Social Studies Education, Gazi University, Faculty of Gazi Education, Ankara, Turkey \\ ${ }^{2}$ Department of Guidance and Psychological Counseling, Gazi University, Faculty of Gazi Education, Ankara, Turkey \\ Correspondence: Osman Sabanc1, Department of Social Studies Education, Gazi University, Faculty of Gazi Education, \\ Ankara, Turkey.
}

Received: March 1, 2018

Accepted: April 27, $2018 \quad$ Online Published: May 31, 2018

doi:10.11114/jets.v6i6.3068

URL: https://doi.org/10.11114/jets.v6i6.3068

\begin{abstract}
During student development, enriching academic and psychosocial activities in accordance with different educational needs of students is important. This study aims to identify primary school teachers' opinions in Turkey, Czech Republic, Italy, and Germany. The opinions of teachers were investigated and compared on the individual skills, interests, intelligence, and abilities of students in the inclusive education environment with talented and gifted students. Moreover, methods, techniques and strategies they implemented in behavioral management, development and the bonding of the students to each other were analyzed. The study is a descriptive qualitative research. Layered sampling was used from the purpose sampling methods. The study group consisted of 248 elementary school teachers. In data analysis, content analysis was used. To ensure validity and reliability of the study, the coder reliability coefficient, the expert opinion, the confirmability strategy techniques were used. In Czech Republic, Turkey and Italy the teaching dimension for determining the students' interests, abilities and intelligence was emphasized, while Germany the dimensions of co-operation with parents and stakeholders was highlighted. Teachers participating in the development of positive behavior prioritised the communication process, stimulating educational activities in the management of unwanted behavior and the bonding of students with each other. Teachers' educational effectiveness-based responses in relation to the management of students' interests, skills and intelligence, development and behaviour revealed that teachers cannot parse the approaches that correspond to different problem areas. It was observed that there were not enough applications to contribute to the psychosocial development of students with different developmental characteristics.
\end{abstract}

Keywords: inclusive education, elementary school students, student recognition, elementary school teacher, behavior management

\section{Introduction}

\subsection{Introduce the Problem}

In the educational process where the individual's mind, body, emotional, and social abilities are developed at the highest level and where skills, behavior and information are gained in accordance with the specific objectives (Akyuz, 2008), students in different educational needs are expected to realize their existing potentials by taking their individual characteristics into consideration. In particular, with the reflection of humanistic approaches to education, such characteristics as recognizing students, gaining value for them, determining their learning needs, configuring education in accordance with learning styles, revealing their interests, and abilities by enhancing student participation are emphasized in the education process (Bacanli, 2011). It is believed that each student is unique and has its own unique development speed/rate and characteristics (Yesilyaprak, 2012).

\footnotetext{
"This study has been developed and produced from the project numbered "2015-1-TR01-KA201-021420", titled "Strategies for Talented and Gifted Pupils' Teachers" which is accepted within the framework of Turkish European Union Erasmus + Mixed School Education program. Furthermore, the study was also presented as an oral presentation at Gazi University between the dates of May 4-6, 2017 on the International Conference on Gifted Students: New approaches and educational applications in the context of the students' interest in the inclusive education environment, the ability and educational practices aimed at identifying and developing their intelligence.
} 
In this context, the traditional teacher and classroom environment were superseded by the teacher who configures the classroom atmosphere and the educational process in line with the different educational needs of the students. The development of the interests and abilities of each student and the classroom environment where every student is accepted as they are and where educational and communicative barriers are eliminated. In the learning process, the students' inner experiences are taken into consideration, and the active learning methods of creativity and inner motivation are used predominantly. In this process, programs involve such features as learning by feeling, observing, thinking, and doing (Kincal, 2006).

In the classrooms there are students with different developmental, mental, social, and cultural characteristics. In addition to considering the psychosocial needs of the student, the evaluation of the educational processes and the teacher's ability to configure the education by revealing the interests and abilities of students are of crucial importance. Besides, it is an indispensable requirement for students with special needs to study in the formal training process with their peers in terms of human rights and social justice. For these reasons, the inclusive education, which means that students with special needs are trained with their peers, has been one of the most common topics recently. Inclusive education refers to the emergence of the internal potentials of students and the configuration of the school environment according to the needs of the students in social development (Havel \& Kratochvílová, 2014). The use of different ways in learning, respecting the differences, and supporting students' abilities will improve the opportunity to solve problems in different ways and respect cultural differences.

The inclusive education is also considered as one of the effective factors in structuring teachers' attitudes toward students who need special education (Rombo, 2006). In addition, the beliefs of teachers play an important role in structuring their attitudes towards (Cook, Semmel \& Gerber, 1999). UNICEF (2014) points out that although it may be considered as a luxury or as a responsibility of experts, the inclusive education should be emphasized since each children has right to access a high quality of education. According to Corbett (1999ab), inclusiveness is regarded equivalent to educational excellence because the environment is arranged to meet the needs of the students who are in need of different educational practices (Cummings, 2000).

In the context of inclusive education, educators are expected to adopt the philosophy of inclusive education and be willing to apply it. The inclusive education requires commitment to culture, respect for differences, and access to the learning opportunities for all students. Therefore, educators at all levels of education are expected to implement the philosophy, laws, and relevant regulations of the inclusive education. In inclusive education, it is essential for students to be placed in public schools regardless of their skill levels. There are a number of issues in implementing inclusive education. First, all curriculums should include necessary adaptations and modifications within the framework of the inclusive education. However, it is highlighted in the literature to have a single curriculum that is accessible for all students who need special education. Second, the assessment process should include the adaptation and the use of alternative assessments, methods, and techniques. In this context, the realization of the evaluation in a clearly defined structure, guidelines for students to participate in the evaluation process, clear definition of the scoring criteria and procedure, high technical quality in terms of academic achievement standards, validity, and reliability of assessment are required for accessibility. Third, in the adaptation of teaching, such strategies as behavioral approach practice, review and practice, making formative evaluation and giving feedback, peer teaching, collaborative teaching, classroom climate, memory techniques and self-regulation teaching, cognitive strategy education should be applied in the education process. In line with the inclusive education principles, the cooperation of parents and professionals such as teachers, therapists, speech and language therapist, support from assistant teachers should be facilitated. Finally, leadership should involve creating and developing a positive school culture, environment and implementing it for the purposes of the school (Fraser \& Walberg, 2005; Mitchell, 2015).

The present study aims to review the applications of inclusive education in four countries: Turkey, Czech Republic, Italy, and Germany. In Turkey, education of individuals requiring special education is defined in special education regulations in the inclusive education instruction by the Ministry of National Education. In Turkey individuals with special needs receive education with their peers in both private and state schools at all levels of education. Therefore, physical, social and psychological environments need to be arranged in the schools providing inclusive education (MONE, 2016). In this context, UNICEF and Turkey carried out a situation analysis study. In this study, inclusive education is considered as an approach which recognizes and respects differences and which consists of attitudes and perceptions of the society. An important part of the literature in Turkey in the inclusive education field has focused on students with disabilities. However, the literature lacks studies that centered on talented and gifted students in inclusive education. Studies on inclusive education indicate that teachers' attitudes are one of the key factors of inclusive education, and that the attitudes of teachers are crucial for the development of the inclusive education system (Corbett, 1999ab; Meijer, 2001; Havel \& Kratochvílová, 2014; Duskun, 2016). In Turkey, in order to receive inclusive education, it is required for an individual to be diagnosed as an individual with special needs. Therefore, the purpose of diagnosing in the inclusive 
education is the preparation of educational applications and consulting programs that fit to the individual characteristics of the students. In this context, the individual characteristics of the students, the overlapping of contents of the educational programmes, and the early diagnosis are important features. In the program process, the class level of the student audience to which the instruction will be applied, the attitudes and expectations of the partners related to the program, are among the effective factors in the creation of educational systems. The program models applied can be classified in the form of private school, school in school, full private class, partially private class, mixed class, weekend, and summer schools (Sak, 2008).

In Czech Republic, inclusive education is a new developing area. However, the national curriculum is capable of identifying and developing the needs of talented people who can succeed in competing with other countries (Reid \& Boettger, 2015). The term "inclusive education" is used in Czech Republic and is applied to all students in the schools. In the design of objective and educational output, it is stated that teachers in Czech Republic are inclined to choose extended educational strategies for the implementation of a more specific teaching strategy for the development of students' abilities. Teachers' practices are not only in the form of expert and family collaboration and the diagnosis of students, but also in the form of definining specific training methods, training procedures, evaluation and content adaptation, and the creation of an appropriate environment for the psychosocial and physical situations of the students. It is envisaged to provide the teacher with the ability to think about how to provide and use the process elements (Kratochvílová \& Havel, 2014). In this education process, integration, special classes, and special schools for talented children are referred to as the main components. In Czech Republic, applications such as the individual learning program, acceleration, enrichment, early enrollment in primary education, class jumping, etc. are notable in the teaching of talented and gifted children. In addition, the student clubs offer support for gifted education, through which local administrations, primary schools and family cooperation have been established (Reid \& Boettger, 2015).

The education system in Germany differs in states. Educational institutions in all states are financed by the federal state and the local administrations (Demirel, 2000, p. 104). Reid and Boettger (2015) observe that in all inclusive education-related practices in Germany the states are encouraged to promote early school enrollment in primary education and to encourage the flexible school system, involving class jumping. Within the context of the inclusive education, the process of identifying talented and gifted students is carried out in cooperation with teachers, families and even children. Child-specific courses are also provided nationwide by non-profit organizations. The gymnasia tradition which focuses on improving academic success still exists in German education system. Recognition of the intellectual needs of talented and gifted children in their schools and social interactions are regarded as the issues that are strongly emphasized on the development of students ' abilities. In addition, some states have programs and applications that contain support for the education of talented students in their education regulations (Levent, 2011).

In Italy, the inclusive education has been included in national politics since the 1970s. In Italy, laws and inclusive education practices are integrated. Almost all students in the inclusive education are educated in the same educational environment with typical students. Students' specific education needs are addressed through individualized education programs. Bringing all students together, willingness to accept children, accessibility of resources, and influence on the family structure are among the factors that are effective on the applications of teachers in Italy (Groppelli, 1995; Peters, 2003; Begeny \& Martens, 2007, D’Alessio, 2011). In Italy, the definition of a gifted individual focuses on promoting creativity and moral development (Comunian \& Gielen, 2000). Looking at the applications which participating in the study, it is emphasized that successful and fair education cannot be provided unless there is a school program covering all talented children (including those who fail). In the European countries in this study, schools, parents, and teachers are involved in the identification of talented and gifted children in the inclusive education (Reid \& Boettger, 2015).

Other element in the inclusive education framework is the teacher. Although inclusive education is the responsibility of all teachers, the knowledge and skills that teachers should have are now defined. In this process, teachers are encouraged to configure the learning process, taking the course attendance and the needs of the students in school and society into consideration. The values and attitudes of the inclusive education environment are very important. In addition, inclusive education is considered as a process based on the diversity of the needs of all students; appeals to the diverse needs of education and provides answers. It is observed that teachers with an advanced sense of responsibility are more effective in the educational process of their students. It is expressed as a dynamic process requiring continuous support and professionalism in the professional development of teachers in terms of inclusive education. However, it seems that teachers are not taught much about gifted children and inclusive education as part of their teacher training (Reid \& Boettger, 2015). The inclusive education process is not completed by adapting it to the school and classroom environments. In addition, it includes an ongoing reflection and self-evaluation process in the entire school community (Grimes, 2013).

In the inclusive education environment, students with different training needs are trained together, which will help to configure their education in accordance with their recognition, characteristics, and training needs. At this point, one of 
the subjects that the teacher will insist is the configuration of the education according to the characteristics of the gifted students. In the literature, different definitions of talented and gifted have been provided. According to Marland, gifted children are those recognized by specialists, who can demonstrate high performance, because of their extraordinary superior abilities (Marland, 1972, p. IX). Gagne (2004) distinguishes high talent and talent by origin. The superior ability is described as an innate condition not earned with education; talent is stated as an acquired condition with education. Ataman (2014) identifies the gifted individuals by being at the highest level in terms of mental performance according to their peers and emphasis on the creativity characteristics. When gifted students are evaluated in developmental terms, they exhibit different developmental characteristics in different life periods and appear to be more advanced from their peers (Daglioglu, 2014). According to another definition, intellectual giftedness is the high success and performance in one or more areas in mental ability, special academic abilities, creativity, art, leadership, and sports (physical) (Tortop, 2015). Before the age of ten, they begin to read early, show good performance in solving arithmetic problems and perform adult level performance in areas such as music, mathematics, painting and creative writing (Caglar, 2004; Davasligil \& Leana, 2004; Sak, 2015; Sak, Ayas, Bal Sezerel, Opengin, Ozdemir \& Demirel Gurbuz, 2015). Gifted children also enjoy mental activities. They can establish cause-effect relationship and appreciate the values of righteousness, equality and justice. Besides, their organization and systematization abilities and capabilities are developed (Webb, Gore, Amend \& DeVries, 2016). Therefore, additional resources and opportunities are required to meet these students ' specific learning needs (Cakmak, 2001).

Gifted children are able to process analytical knowledge such as detection, perceptual distinguishing, memory and recall. They are also very successful in analytical operations such as comparison, pairing, and mental configuration. In terms of cognitive development, it is observed that gifted children perceive abstract materials much faster and more accurately. Moreover, their creative problem solving skills are advanced and they show high-level performance in terms of mathematical reasoning. However, when evaluating these skills, it is necessary to disregard the knowledge that simultaneous development decreases as the skill levels of the gifted children rise (Daglioglu, 2014). Gifted individuals can empathize; approval is important for them and they have high energies (Webb, Gore, Amend \& DeVries, 2016). The willingness to succeess, extreme perfectionism, hypersensitivity, intense tension, instant emotional changes, the inability to express themeselves in a complete and accurate manner (imprisonment), introveness, quick-bored features are among the emotional problems seen in talented and gifted individuals (Enc, 2005; Leana-Tascilar, Ozyaprak, Gucyeter, Kanli \& Camci-Erdogan, 2014).

It is regarded as a natural conclusion that the students with different genetic characteristics from different social backgrounds/environments and families have different mental and psychosocial aspects. These students affect the climate of the school and the class and they are influenced by the class climate. Ensuring a purposeful and comfortable learning environment, motivating students, providing a positive interaction between teacher and student, the appearance and characteristics of the class, increasing the existing self-esteem of the student are expressed as the class climate (Cakmak, 2003). By providing a class climate, academic and psychosocial development of students take place. A positive class environment leads to expected students' behaviour and plays a preventive role in the formation of undesirable behavior.

Although the aim of education is to provide the development of behavior in the desired direction of the individual, sometimes undesirable behavior can be observed at school. In the origin of the unwanted behavior, according to the psychoanalytic theory, problems related to childhood experiences and psychosexual development and the imbalance between the individual's biological, psychological and social self, called the id, ego and super ego ensuring this balance, the unhealthy use of ego defense mechanisms is included (Freud, 1997). According to the behavioral approach, the cause of undesirable behavior is the misuse of conditions and reinforcements. The proper use of reinforcement, proper behavior repertoire, generalization, and the appropriate use of distinguishing are factors that increase the frequency of positive reactions. In addition, model acquisition and imitation processes are among the elements that configure the behavior of a student (Kilicci, 2006). According to the humanist and existential approach, the fundamental motivation of the individuals is to realize their potentials, establish a close relationship and make their life meaningful. If the individuals' basic needs are meet, and if they are accepted, a positive development will be exhibited, otherwise the individual may turn to unhealthy attitudes (Yalom, 2000).

In schools, the most important element in the education process, the development of desired behaviors in students and the correct management of unwanted behaviors are among the aims. Coming to the school regularly and on time, bringing the necessary tools and materials, doing homework, active participation in the class and following the rules are stated as requested behaviors (Erden, 2005). On the other hand, attending to class unprepared, making noise, exhibiting distracting attitudes, showing uncontrolled and impulsive behavior in the classroom, exhibiting problem behaviors such as smoking and theft, unauthorized movement, physical damage to friends and the educational environment, behavior blocking the lessons are expressed as unwanted behaviors. This unwanted behavior may be as a result of the class 
climate, the equipment, the teacher and the student (Ozdemir, 2004).

Gifted childrens' problem areas differ. These students can have problems in interpersonal relationships since their vulnerability rates are increased in parallel with their superior capability level. Moderately superior capabilities increase popularity among friends, while individuals with advanced intellectual abilities have difficulties developing friend relationships. The intense sensitivity and reactivity of these individuals are among the factors that negatively affect relationships. Another problem is that they set hard-to-reach goals and force themselves to be perfect. In terms of suicide, high stress and risk-taking behavior, it can be said that gifted students have different characteristics from typical students and their problems vary among themselves (Ozbay \& Palanci, 2011). The problems in the school environment of gifted students include the difficulty of being patient during learning, setting high standards in the learning process, experiencing disappointment, being bored while waiting for the learning process of their peers (Webb, Gore, Amend \& DeVries, 2016) and academic failure (Levent, 2014).

The identification of unwanted behavior and its origins and reasons will embody the steps to be taken in the management of the students. It is also important to change behavior, not only to change in terms of problematic behavior, but also to keep positive behavior and prevent undesirable behavior with preventive work. Considering that behavior is learned, the analysis of how environmental factors and reinforcements are used related to the formation and development of behaviour, the effect of the teaching processes and programs on unwanted behavior in the classroom, the correct structuring of the meaning of positive behavior for the student will contribute to the increase of requested behaviors (Ataman, 2003).

In the inclusive classroom environment, the role of the teacher in managing the classroom climate as well as the negative behavior is important since it reveals the potential of the student and constructs it in terms of psychosocial development. The teacher must take preventive measures related to instructional, program, and behavior management before unwanted behavior is formed. When the teacher observes unwanted behavior in a student, he needs to assess the strategies for the elimination of the creation and development of that behavior, which will provide a positive contribution as long as the necessary arrangements are made. The teacher needs to be a role model of the behaviors he wants to develop in their students, and take advantage of direct and indirect reinforcement, and cooperation with stakeholders when necessary, which are among the behavior management strategies. The teachers' use of communicative strategies will make the students express themselves correctly and contribute positively to each other's development. In this context, the fundamental principles of communication reflected in the classroom atmosphere can be considered as one of the factors that will help students develop positive behavior and reduce or eliminate unwanted behavior. In addition, when undesirable behavior occurs, the teacher analyses the problem correctly or ignores it when necessary. In this context, warning, making changes in the course, giving responsibility, talking to the student about the problem behavior, school management and cooperation with the family are among the recommended behaviors to the teacher (Basar, 2001).

The main research question of this study is "What are the elementary school teachers' opinions on from Turkey, Italy, Czech Republic and Germany on the recognition and behaviour management of students in the inclusive education environment with talented and gifted students?"

The sub-questions of the research are as follows: (a) "What are the opinions of primary school teachers in Turkey, Czech Republic, Italy and Germany, in the inclusive education environment with talented and gifted students in recognition and behavior management of the students?" (b) What they do in order to determine the individual skills, interests, intelligence and abilities of students?

The findings of the study will be presented under these headings:

1. To determine the individual skills, interests, intelligence and abilities of their students

2. To develop the individual skills, interests, intelligence and abilities of their students

3. Findings on the subject of behavior management

a. How to develop positive behavior in a student

b. How to manage unwanted behavior

4. How to improve peer socialization

\section{Method}

\subsection{Research Design}

This research adopted a descriptive research approach in the qualitative design (Bogdan \&Biklen, 1992; Fraenkel, Wallen \& Hyun, 2012). In this research, the opinions of elementary school teachers' about determination and development of 
students' interest, ability and intelligence, development of positive behavior, management of misbehaver and the inclusion of students having different attributions were investigated. In descriptive studies, the characteristics of events, individuals, groups and physical environments are tried to be described. In addition, different research designs can be used in qualitative research like cultural analysis, phenomenological, theory development, case study, and action research (Buyukozturk, Kilic Cakmak, Akgun, Karadeniz \& Demirel, 2017; Yildirim \& Simsek, 2016; Patton, 2002).

\subsection{Participant (Subject) Characteristics}

The study group consists of primary school teachers who work in Turkey $(\mathrm{n}=77)$, Czech Republic $(\mathrm{n}=71)$, Italy $(\mathrm{n}=$ $50)$, and Germany $(\mathrm{n}=50)$. Information about the teachers participating in the study such as, seniority of teachers, age, gender, class level, and number of students in classrooms, having any seminar for gifted students or in-service training, the use of strategy in classrooms where there are many individual differences among students were addressed in relation to the countries above. The demographic information is presented in Table 1.

Table 1. Demographic information of study group

\begin{tabular}{|c|c|c|c|c|c|c|c|c|}
\hline \multirow{3}{*}{$\begin{array}{l}\text { Countries } \\
\text { Gender }\end{array}$} & \multicolumn{2}{|l|}{ Turkey } & \multicolumn{2}{|c|}{ Cezch Republic } & \multicolumn{2}{|l|}{ Italy } & \multicolumn{2}{|c|}{ Germany } \\
\hline & Female & Male & Female & Male & Female & Male & Female & Male \\
\hline & $\% 78$ & $\% 22$ & $\% 100$ & - & $\% 94$ & $\% 6$ & $\% 80$ & $\% 20$ \\
\hline \multicolumn{9}{|l|}{ Age (years) } \\
\hline $20-25$ & $\% 2.6$ & & $\% 5.6$ & & - & & - & \\
\hline $26-30$ & $\% 2.6$ & & $\% 9.9$ & & $\% 2$ & & $\% 12$ & \\
\hline $31-35$ & $\% 3.9$ & & $\% 11.3$ & & $\% 14$ & & $\% 24$ & \\
\hline $36-40$ & $\% 11.7$ & & $\% 19.7$ & & $\% 10$ & & $\% 64$ & \\
\hline 41 and over & $\% 79.2$ & & $\% 53.5$ & & $\% 74$ & & - & \\
\hline \multicolumn{9}{|c|}{ Professional experinece (years) } \\
\hline \multirow{5}{*}{$\begin{array}{l}1-5 \\
6-10 \\
11-15 \\
16-20 \\
21 \text { and over }\end{array}$} & $\% 2.6$ & & $\% 18.3$ & & $\% 6$ & & $\% 26$ & \\
\hline & $\% 5.2$ & & $\% 14.1$ & & $\% 16$ & & $\% 38$ & \\
\hline & $\% 5.2$ & & $\% 14.1$ & & $\% 12$ & & $\% 6$ & \\
\hline & $\% 26$ & & $\% 28.2$ & & $\% 16$ & & $\% 16$ & \\
\hline & $\% 61$ & & $\% 25.4$ & & $\% 50$ & & $\% 14$ & \\
\hline \multicolumn{9}{|l|}{ Grade } \\
\hline $1^{\text {th }}$ & $\% 10.4$ & & - & & $\% 8$ & & $\% 16$ & \\
\hline $2^{\text {nd }}$ & $\% 27.3$ & & - & & $\% 8$ & & $\% 34$ & \\
\hline $3^{\text {rd }}$ & $\% 31.2$ & & - & & $\% 24$ & & $\% 30$ & \\
\hline $4^{\text {th }}$ & $\% 31.2$ & & - & & $\% 60$ & & $\% 20$ & \\
\hline \multicolumn{9}{|l|}{ Class size (students) } \\
\hline $1-15$ & $\% 5.2$ & & $\% 18.3$ & & $\% 2$ & & - & \\
\hline $16-30$ & $\% 84.4$ & & $\% 81.7$ & & $\% 98$ & & $\% 100$ & \\
\hline $31-45$ & $\% 10.4$ & & - & & - & & - & \\
\hline \multirow[t]{2}{*}{ Inserves training } & Yes & No & Yes & No & Yes & No & Yes & No \\
\hline & $\% 15.6$ & $\% 84.4$ & $\% 5.6$ & $\% 94.4$ & - & $\% 100$ & - & $\% 100$ \\
\hline \multirow[t]{2}{*}{ Use of any strategies } & Yes & No & Yes & No & Yes & No & Yes & No \\
\hline & $\% 53.2$ & $\% 46.8$ & $\% 28.2$ & $\% 71.8$ & $\% 10$ & $\% 90$ & $\% 100$ & - \\
\hline
\end{tabular}

\subsection{Data Collection and Analysis}

The present study is based on the project of the European Union Erasmus + program main action 2- strategic partnerships- mixed school education project called "Strategies for teachers of talented and gifted children". The data was obtained through questionnaires applied to the teachers who worked with children showing typical development at elementary school level, the students who demonstrated the potential for superior capabilities and/or students diagnosed in this regard in the inclusive educational environments. The questionnaire was designed by two experts working in this project, taking the opinions of four teachers who have worked at elementary schools into consideration. After the initial questionnaire was formed, the partner countries were asked to modify it. After the modification process, the coordinator country shaped the final version of the questionnaire. The final survey form consists of four parts. Nevertheless, only the qualitative questions in the questionnaire were analysed in this study.

The first part of the survey includes questions related to 'demographic and personal information (occupational seniority, age, gender, grade level and number of students, the situation of whether or not to take in-service or seminar for gifted students in the context of inclusive education, use of strategy or method in heterogeneous classrooms). The second part consists of 25 questions developed with different dimensions, with a 5-point likert scale type. The third part is composed of 3 multiple choices and 6 open-ended questions. The fourth section consists of open-ended questions about the activities that teachers perform in their class to develop positive behaviors, the practices they perform when they encounter unwanted behaviors, and the activities to bond students with different characteristics with each other. The final form was implemented in each country after the necessary permissions were granted. Thus, in order to implement 
the questionnaire in Turkey, permission was taken from the Ankara Provincial Directorate of National Education. The data collection was carried out on a voluntary basis.

In the analysis of the data, content analysis technique was used to determine patterns including coding and categorization. Content analysis is based on defining qualitative data according to their similarity and meaning and is often used in analyzing a text (interview form, journal, document, etc.) (Patton, 2002; Yildirim \& Simsek, 2016). During the data collection, verbal instructions were presented and necessary explanations were made. In addition, additional questions from participants were answered. This study deals only with open-ended questions in the third and fourth part of the survey. In the reporting of open-ended questions, the frequency values for the categories were conducted through direct quotations from the participants' data. In the presentation of the data the following procedure was used: the first character refers to the country, the second character the participant number, the third character the gender of the participant, and finally the information about the professional seniority. For Turkey TR, for Czech Republic CZ, for Italy IT and for Germany DE abbreviations were used. Since a participant specified multiple opinions, the number of participants and the number of opinions varied. The percentage of compliance for each sub-problem in ensuring the reliability between encoders was calculated as the consensus/ (opinion separation + consensus) x100 (Miles \& Huberman, 1994). The interrater reliability among three encoders was also calculated. The interrater reliability was $44.5 \%$ for all encodings for the first item and $67 \%$ of the data obtained for the second item. For the other items, it corresponded to $31,04 \%$ of all the data. The values for this are presented in table 2 .

Table 2. Percentage of matching for sub-problems

\begin{tabular}{lllll}
\hline Item & Number of matching codes & $\begin{array}{l}\text { Number of nonmatching } \\
\text { codes }\end{array}$ & Total & Matching percentage \\
\hline 1 & 150 & 12 & 162 & $\% 92,59$ \\
\hline 2 & 164 & 16 & 180 & $\% 91,11$ \\
\hline $3 \mathrm{a}$ & 60 & 8 & 68 & $\% 88,23$ \\
\hline $3 \mathrm{~b}$ & 181 & 23 & 204 & $\% 88,72$ \\
\hline 4 & 158 & 4 & 162 & $\% 97,53$ \\
\hline Total & 713 & 63 & 776 & $\% 91,88$ \\
\hline
\end{tabular}

For each sub-problem, the congruent percent was calculated as $92.59 \%, 91.11 \%, 88.23 \%, 88.72 \%$ and $97.53 \%$. The overall congruent percent was calculated as $91.88 \%$. Item-based and generalized coherence percentages indicate that study is reliable.

Direct quotations were included in the study to ensure external validity. Moreover, the research process was described in detail. For this purpose, purposeful sampling method was used to determine the data sources involved in the research. In this context, expert examination was applied in various stages of the research (Yildirim \& Simsek, 2016).

\section{Results}

In this section, the activities of the teachers working in Turkey, Czech Republic, Italy, and Germany in identifying and improving the individual interests, talents, and intelligences of the students in the inclusive education environment, improving students' positive behaviors, changing their undesirable behaviors and bonding the students with each other are included. The opinions of teachers were compared among countries. In the following part of the research, the findings were presented in the context of sub-problems.

\subsection{To Determine Individual Skills, Interests, Intelligence and Abilities of Their Students}

The findings of primary school teachers who worked in Turkey, Czech Republic, Italy and Germany about determining their opinions about their work about the individual skills, interests, abilities and intelligence of their students in the inclusive education environment are presented in table 3.

Table 3. The distribution of what teachers do to determine the individual skills, interests, abilities and intelligence of students

\begin{tabular}{|c|c|c|c|c|c|}
\hline Countries & Turkey & Czech Republic & Italy & Germany & Total \\
\hline Category & $\mathrm{f}$ & $\mathrm{f}$ & $\mathrm{f}$ & $\mathrm{f}$ & f \\
\hline Engaging activities that reveal interest and abilities & 35 & 10 & 22 & 5 & 72 \\
\hline Using different teaching methods and techniques & 24 & 31 & 34 & 3 & 92 \\
\hline Using diagnostic methods & 5 & 7 & - & - & 12 \\
\hline Let make individual-group work & 8 & 3 & 4 & 1 & 16 \\
\hline Evaluation & 8 & 3 & 11 & & 22 \\
\hline Collaborate with stakeholders & - & 10 & - & 98 & 108 \\
\hline Creating an appropriate learning atmosphere & 13 & 9 & 18 & 9 & 49 \\
\hline Total & 93 & 73 & 89 & 116 & 371 \\
\hline
\end{tabular}


Table 3 indicates that, in order to determine the individual skills, interests, intelligence and abilities of their students, teachers used the following categories: cooperating with stakeholders $(\mathrm{f}=108)$, using different teaching methods and techniques ( $f=92$ ) and engaging activities that reveal their interest and abilities $(f=72)$.

When the data obtained from the countries is evaluated within itself, it was found that cooperation with stakeholders in Germany ( $f=98$ ), the interest and capabilities of the engaging activity in Turkey ( $f=35$ ), and using different teaching methods and techniques in Czech Republic $(\mathrm{f}=31)$ and $(\mathrm{f}=34)$ in Italy were the most used activities.

Examples of the data presented by teachers for the most frequent categories of the countries are as follows:

"I diversify activities or offer preferences" (TR, 13, F, 25).

"I organize different types of studies/tasks and activities" (CZ, 87, F, 3).

"I apply activities that each student can participate in according to their abilities" (IT, 151, M, 25).

"I give students different assignments/tasks, and I want them to discuss their problems" (DE, 199, F, 26).

\subsection{To Develop Individual Skills, Interests, Intelligence and Abilities of Their Students}

Opinions about the findings of primary school teachers from Turkey, Czech Republic, Italy and Germany working in the inclusive education environment on how to develop individual skills, interests, abilities and intelligence of their students are presented below.

Table 4. The distribution of teachers' practices to improve the individual skills, interests, abilities and intelligence of the students

\begin{tabular}{|c|c|c|c|c|c|}
\hline Countries & Turkey & $\begin{array}{l}\text { Czech } \\
\text { Republic }\end{array}$ & Italy & Germany & Total \\
\hline & $\mathrm{f}$ & $\mathrm{f}$ & $\mathrm{f}$ & $\mathrm{f}$ & $\mathrm{f}$ \\
\hline $\begin{array}{l}\text { Making interest-enhancing activities (group work, using creative thinking, } \\
\text { giving feedback) }\end{array}$ & 20 & 30 & 10 & 2 & 62 \\
\hline Responsibility / Assignment & 3 & 23 & 13 & 12 & 51 \\
\hline To show an individual approach (using material tailored to individual needs) & 6 & 25 & 12 & 4 & 47 \\
\hline $\begin{array}{l}\text { Using different teaching methods and techniques (following technology and } \\
\text { innovations) }\end{array}$ & 17 & 11 & 15 & 48 & 91 \\
\hline Respecting students' ideas & 14 & 18 & 3 & - & 35 \\
\hline $\begin{array}{l}\text { Providing an appropriate learning atmosphere } \text { (motivating-using } \\
\text { reinforcement, communicating) }\end{array}$ & 8 & 15 & 9 & 3 & 35 \\
\hline Collaborating with stakeholders (other experts, parent) & 3 & 9 & 1 & 56 & 69 \\
\hline Total & 71 & 132 & 63 & 126 & 391 \\
\hline
\end{tabular}

According to Table 4, the most used activities to develop students' individual skills, interests, talents and intelligence are as follows: using different teaching methods and techniques ( $f=91)$, cooperating with stakeholders $(f=69)$ and activities that enhance interest and abilities $(f=62)$. When the data of the countries are evaluated seperately, teachers in Germany were found to be in the forefront of co-operation with stakeholders ( $f=56$ ), teachers in Czech Republic preffered to exhibit an individual approach $(f=25)$, teachers in Turkey used activities that enhance interest and abilities $(f=20)$, and teachers in Italy emphasized the use of different teaching methods and techniques $(f=15)$.

Examples of the data presented by teachers for the most frequently repeated categories of the countries are as follows:

"I apply different activities" (TR, 16, F, 37).

"I implement project-based teaching, teamwork and individual approach" (CZ, 107, F, 8).

"I recommend workshops, art, philosophy, etc. to reveal the students' interests and abilities" (IT, 157, F, 22).

"I'll let them keep a learning diary, collaborate with experts and parents" (DE, 216, F, 3).

\subsection{Findings on the Subject of Behavior Management}

Primary school teachers'opinions about behavioral management in the inclusive education environment are presented as sub sections below.

\subsubsection{How to Develop Positive Behavior in a Student}

The work of primary school teachers serving in the inclusive education environment to develop the positive behavior of students, are presented in table 5 .

The data contained in table 5 was obtained from teachers who serve in Turkey $(n=71)$, Czech Republic $(n=58)$, Italy $(\mathrm{n}=50)$ and Germany $(\mathrm{n}=50)$. 
Table 5. The distribution of teachers' efforts to develop positive behaviors of students

\begin{tabular}{|c|c|c|c|c|c|c|}
\hline \multirow{5}{*}{ 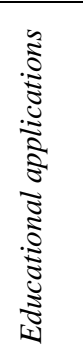 } & \multirow{2}{*}{ Category } & \multicolumn{5}{|c|}{ Republic } \\
\hline & & $\mathrm{f}$ & $\mathrm{f}$ & $\mathrm{f}$ & $\mathrm{f}$ & $\mathrm{f}$ \\
\hline & $\begin{array}{l}\text { Enrichment of activities (different tasks based on abilities, development } \\
\text { of creative thinking, peer training) }\end{array}$ & 16 & 10 & 10 & 2 & 38 \\
\hline & Creating a contemporary learning environment & 1 & 3 & 6 & - & 10 \\
\hline & Raising the motivation and interest of a student & 20 & 4 & 5 & - & 29 \\
\hline & Subtotal & 37 & 17 & 21 & 2 & 77 \\
\hline & No idea & - & 5 & & - & 5 \\
\hline$\approx \bar{\Xi}$ & Presenting individual approaches-individualizing learning & 4 & 3 & 8 & 20 & 35 \\
\hline 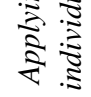 & Individual and group evaluation & 2 & 5 & 5 & 1 & 13 \\
\hline & Subtotal & 6 & 8 & 13 & 21 & 53 \\
\hline 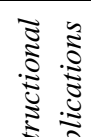 & $\begin{array}{l}\text { Choosing the appropriate learning method and technique, organizing the } \\
\text { program (associating instructional processes with real life, strengthening } \\
\text { the curriculum) }\end{array}$ & 14 & 19 & 10 & 4 & 47 \\
\hline ఏิ & Educational and social group studies & 3 & 3 & - & 23 & 29 \\
\hline & Subtotal & 17 & 22 & 10 & 27 & 76 \\
\hline$\infty$ & $\begin{array}{l}\text { To communicate effectively (respecting and trusting students' ideas, } \\
\text { setting rules with the student) }\end{array}$ & 39 & 19 & 18 & 51 & 127 \\
\hline 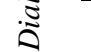 & Supporting positive behavior & 38 & 19 & 9 & 5 & 71 \\
\hline & Get support from stakeholders & 5 & 3 & & & 8 \\
\hline & Subtotal & 82 & 41 & 27 & 56 & 206 \\
\hline & TOTAL & 142 & 93 & 71 & 106 & 412 \\
\hline
\end{tabular}

In table 5, a large majority of teachers who participated in the study to develop the positive behavior of their students indicated that they carried out communication activities $(f=206)$. It is also observed that they were involved in educational applications $(f=77)$ and instructional applications $(f=76)$. When data is addressed in terms of countries, the teachers in Turkey were found to use an efficient communication $(f=82)$ and work towards educational applications ( $f=37$ ). On the other hand, the individual approach $(f=21)$ and instructional applications $(f=27)$ were seen to be predominant by the answers of the teachers $w$ in Germany comparing to other participating countries.

Examples of the data presented by teachers for the most frequently repeated categories of countries are as follows.

"I will emphasize the positive behavior and make sure that all students are noticed. I honor my student "(TR, 15, F, 20).

"I create a positive-class atmosphere, help students develop positive friendships, give frequent feedback on students ' behaviour, and support active participation of students" (CZ, 78, F, 18).

"I let students establish positive relationships and involve everyone in class activities" (IT, 192, F, 26).

"I create common rules and rituals with my students" (DE, 242, M, 8).

\subsubsection{How to Manage Unwanted Behaviour}

The work of primary school teachers in terms of changingunwanted behavior of students is presented in table 6 .

The data in table 6 was obtained from teachers who serve in Turkey $(n=67)$, Czech Republic $(n=58)$, Italy $(n=50)$ and Germany $(\mathrm{n}=50)$. 
Table 6. The distribution of teachers ' efforts to change the unwanted behavior of students

\begin{tabular}{|c|c|c|c|c|c|c|}
\hline & Countries & Turkey & $\begin{array}{l}\text { Czech } \\
\text { Republic }\end{array}$ & Italy & Germany & Total \\
\hline & Category & $\mathrm{f}$ & $\mathrm{f}$ & $\mathrm{f}$ & $\mathrm{f}$ & $\mathrm{f}$ \\
\hline \multirow{3}{*}{ 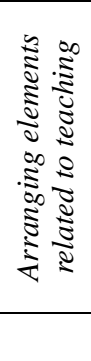 } & $\begin{array}{l}\text { Strategy, implementing different teaching } \\
\text { methods and techniques (encouraging } \\
\text { problem solving in different ways, giving } \\
\text { real-life examples, using peer mediation, } \\
\text { implementing prevention program, giving } \\
\text { responsibility) }\end{array}$ & 98 & 34 & 13 & 2 & 147 \\
\hline & $\begin{array}{l}\text { Individualizing Learning (individual and } \\
\text { group work) }\end{array}$ & 6 & 4 & 3 & 62 & 75 \\
\hline & Subtotal & 104 & 38 & 16 & 64 & 222 \\
\hline \multirow{5}{*}{ 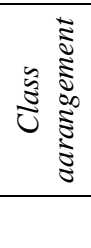 } & Arrange a learning environment & 16 & 5 & 1 & - & 22 \\
\hline & Motivate the student & 12 & 1 & 1 & - & 14 \\
\hline & Setting rules with the student & - & 3 & 3 & - & 6 \\
\hline & Common respect development & 5 & - & 4 & - & 9 \\
\hline & Subtotal & 33 & 9 & 9 & - & 51 \\
\hline \multirow[t]{3}{*}{$\begin{array}{l}\stackrel{0}{0} \\
\stackrel{\Xi}{0}\end{array}$} & $\begin{array}{l}\text { Effective communication (highlighting the } \\
\text { outcome of positive-negative behavior, } \\
\text { recognition of the student's opportunity to } \\
\text { express himself) }\end{array}$ & 43 & 15 & 38 & 1 & 97 \\
\hline & Interviewing and collaborating with parents & 1 & 8 & 2 & - & 11 \\
\hline & Subtotal & 44 & 23 & 40 & 1 & 108 \\
\hline \multirow{6}{*}{ 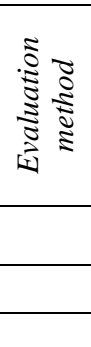 } & Individual and group evaluation & 3 & 2 & 5 & & 10 \\
\hline & $\begin{array}{l}\text { Take advantage of tests to determine the } \\
\text { source of the problem }\end{array}$ & 6 & - & - & - & 6 \\
\hline & Get expert help & 1 & 14 & - & - & 15 \\
\hline & Subtotal & 10 & 16 & 5 & - & 31 \\
\hline & No idea & - & 3 & - & - & 3 \\
\hline & TOTAL & 191 & 89 & 70 & 65 & 415 \\
\hline
\end{tabular}

When educational practices that teachers do to change unwanted behavior in students were examined, studies related to teaching $(f=222)$, applications for communication $(f=108)$, studies to arrange classroom atmosphere $(f=51)$ and studies to adapt the evaluation method $(f=31)$ were found to be used. The most used practices of the teachers who serve in Turkey was found to be the regulation of the teaching-related elements $(f=104)$. However, teachers in Germany placed more emphasis on the individualization of teaching $(\mathrm{f}=64)$ than teachers from other countries.

Examples of the data are as follows:

"I have a private interview with the student. I will inform the student's parents about this and listen to their opinions. To give a positive attitude to the student, I specify a common solution path. I emphasize what needs to be done and work in this direction."(TR, 57, F, 33).

"I create a positive-class atmosphere, use active learning methods, change activities according to their needs, check if learning content is understood, and try to avoid burnout." (CZ, 81, F, 18).

"We try to understand the reasons for negative behavior with my students and indicate the discomfort posed by negative behavior, and I create a supportive environment in line with respect to the values of each individual." (IT, 177, F, 28)

"I organize informative activities for students, and make group discussions" (DE, 243, M, 9).

\subsection{How to Improve Peer Socialization}

The opinions of the primary school teachers on what they do to make the students socialize with each other are presented in table 7 .

The data contained in table 7 were obtained from teachers who serve in Turkey $(n=62)$, Czech Republic $(n=26)$, Italy $(\mathrm{n}=49)$ and Germany $(\mathrm{n}=50)$. 
Table 7. The distribution of the practices of teachers to establish peer socialization

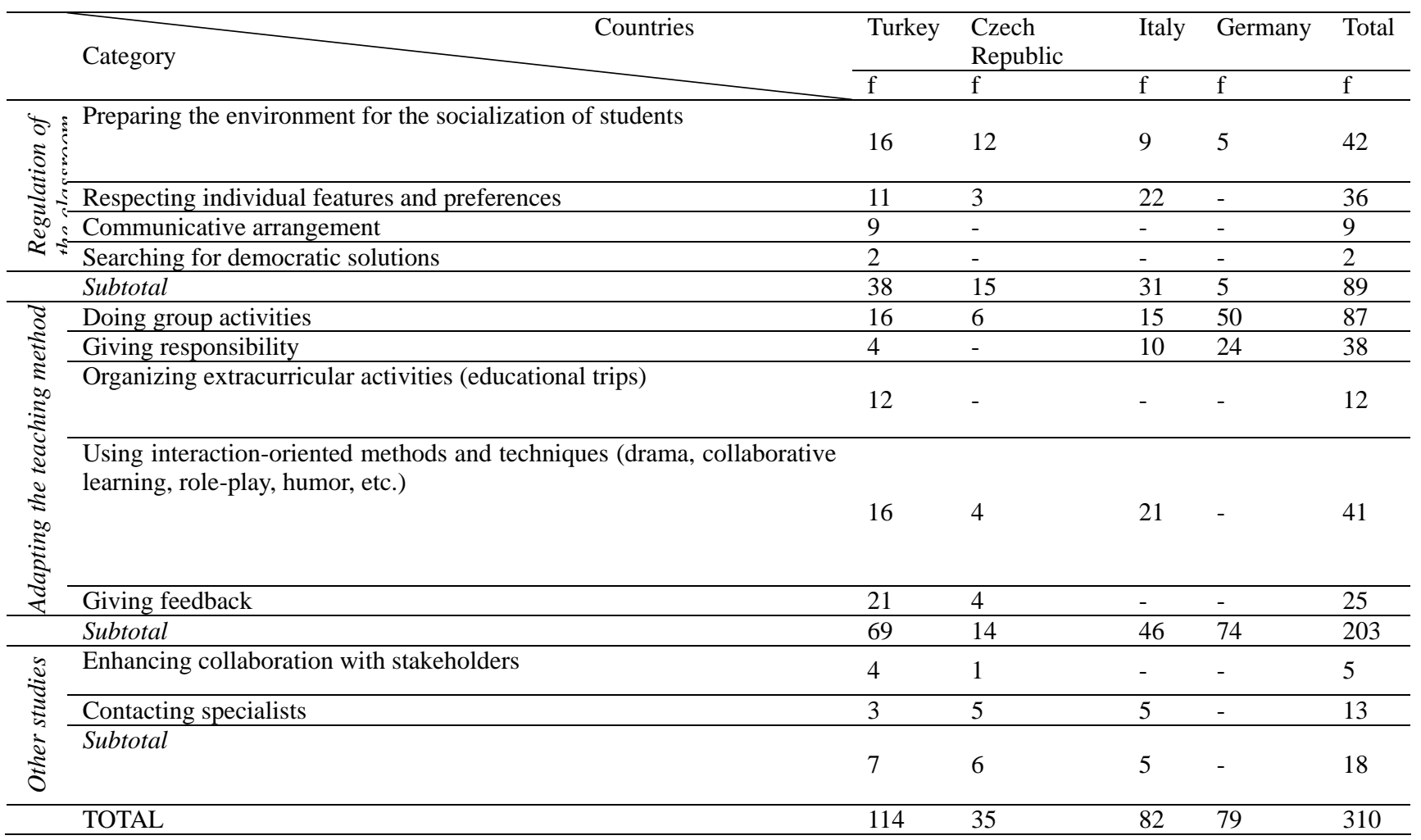

The most preferred practices to socialize the students with each other by the teachers in the inclusive educational environment was to adapt the teaching method $(\mathrm{f}=203)$. This was followed by the arrangement of the classroom climate in accordance with the students ' bonding to each other $(\mathrm{f}=89)$ and other studies $(\mathrm{f}=18)$. Studies on the adaptation of the teaching method was mostly indicated by the teachers $(f=74)$ in Germany. Teachers in Turkey $(f=38)$ were found to be more involved in the organization of the classroom climate.

Examples of the data presented by teachers for the most frequently repeated categories of the countries are as follows:

"I create group workshops, group games, and an environment where responsibility-related activities can be done together. I pay attention to being objective and engaging in my behaviors." (TR, 80, M, 19)

"I will ensure that students participate in school activities." (CZ, 100, F, 23)

"I give students roles to reveal the potential of each of the students and I do group work." (IT, 191, F, 23)

"I make a daily group discussion and organize versatile learning materials." (DE, 201, M, 14)

\section{Discussion and Conclusion}

This study aimed to investigate the opinions of teachers on recognition and behavior management of the students in Turkey, Czech Republic, Italy and Germany in the inclusive education environment with talented and gifted pupils. In this context, teachers' educational applications to identify and develop individual interests, talents and intelligences of the students, developing positive behaviors in students, changing undesirable behaviors, and bonding students with each other in the context of inclusive education are compared in terms of countries. In their research in the 32 countries of the European continent, Manzano-Garcia \& Fernandez (2016) have determined that all countries support the inclusive education in their own legislation.

Teachers who participated in the study in the inclusive educational environment with talented and gifted students, often preferred educational practices such as using different teaching methods and techniques, engaging with stakeholders to identify their students' interests, abilities and intelligence and doing activities that will reveal interests and talents. When results are evaluated in terms of countries, it can be stated that Czech and German teachers were predominantly involved in educational practices aiming at collaborating with stakeholders. On the other hand, teachers in Italy and Turkey were found to be predominantly involved in performing activities and using different teaching methods and techniques. The activities of revealing the interests and talents and using different teaching methods were emphasized by Italian teachers. This situation may be because of reflections of the Italian education system which emphasizes participation in educational processes (Yilmaz, 2013). One of the remarkable findings of the study is that diversification 
of teaching methods and techniques and and the inclusion of other elements in the education were considered as one of the important elements of the inclusive education by the teachers working in Czech Republic, which is an important feature of Czech educational system (Kratochvílová \& Havel, 2014; Havel \& Kratochvílová, 2014 ). In addition, it can be said that teachers benefitted from educational activities such as using diagnostic methods, doing individual andgroup work, making evaluations and creating an appropriate class atmosphere. When educational practices of teachers to determine the students' interests and abilities in the inclusive education environment with talented and gifted students are evaluated in terms of today's education principles, it can be concluded that the given educational applications will allow the students to recognize themselves and reveal their abilities. In particular, using different teaching methods and techniques, engaging educational practices that reveal the interests and abilities, the arrangement of individual and group work and organizing the learning atmosphere in which the students can express themselves comfortably will contribute positively to the social emotional development of the students. In terms of teacher qualifications, the importance of the specified applications is among the highlighted subjects (Seferoglu, 2004).

The identification of the students' internal potentials, the school and its surroundings, using different teaching methods are among the important applications in the context of the inclusive education (Rombo, 2006; Havel \& Kratochvílov, 2014). The enrichment of methods and techniques will ensure the planning of teaching in accordance with the learning styles of students with different learning characteristics (Saban, 2002). Cooperating with stakeholders which is strongly emphasized in the inclusive education (Candace \& Sharon, 2002; Mitchell, 2015) was among the findings preferred by Czech and German teachers. At this point, it is thought that the gymnasia which is anacademically gifted school in Germany and Czech Republic and non-governmental organisations had a leading role in the education system (Greger \& Walterova, 2007; Janowski, 2007). In addition, it can be stated that a close cooperation of the primary school teachers with colleagues, school psychologists, educational counselors, special education specialists and parents are expected in inclusive education in Germany. This approach overlaps with research findings (Aytacli, 2015). However, Reis \& Renzulli (2004) also stated that, thehome, school and learning environment of talented/ gifted children are not supported sufficiently. According to Avramidis and Norwich (2002), educational environment support could be both physical such as resources, teaching, materials, IT equipment, a restructured physical environment and human-based such as learning, support assistants, special teachers, speech therapists.

It was observed that the teachers in this study participated in a variety of activities in developing their students' interests, talents and intelligence such as collaborating with stakeholders, respecting the students' opinions and giving them responsibilities, following the technological innovations and organizing the learning environment in accordance with the students. It can be stated that the principles such as respect for differences and provideing educational applications that will give students the opportunity to learn, which are frequently highlighted in the understanding of the inclusive education, were included in the opinions of the participants. Students who feel that their abilities are respected will find the opportunity to make these abilities a part of their self. Considering the relationships between social and cultural contexts in the context of education, it is emphasized that the inclusion of students in the context of inclusive education supports motivation, self-esteem, control focus, friend-relationships, class atmosphere and different developmental characteristics contribute to their social emotional development in particular (Acikgoz, 1992; Acikgoz \& Gungor, 2006; Sisman, 2009). In addition, teacher educators overhaul their duties and reorganize how they work with schools, trade unions and other interested groups (Barton, 2003).

The most prominent features of the German educational system such as giving importance to the application, using different teaching methods and techniques and following technological innovations (Ertan Kantos, 2013) were reflected in the present study. The educational practices which the teachers used to identify and develop their students' interests, talents and intelligence did not differ from each other. However, it was found that they used similar educational practices. In addition, when the answers of the teachers are analyzed, it can be said that the educational applications for improving the academic skills were more dominant than the applications for social emotional development. Moreover, teacher quality includes both teacher qualifications and characteristics that influence teachers' instruction and student achievement and motivation (Nilsen, Gustafsson \& Blömeke, 2016).

In the inclusive education environment with talented and gifted students, such educational practices such as developing positive behavior in the student, managing unwanted behavior, and bonding students with each other in terms of comparing teacher practices were presented. In this context, all the teachers in the study, agreed on the basis of effective communication for the development of a positive behavior of the student. These results show that teachers take their students' interactions with their friends into consideration. The ability of teachers to have effective communication skills is one of the primary topics addressed in meeting the academic and psychosocial needs of the students (Webb, Gore, Amend \& DeVires, 2016). Gur (2017) emphasizes that students perform high level learning when the teacher establishes effective and positive relations with the students. Furthermore, she notes that, with the support of the positive behaviors of the students, their motivation will be increased; they will be patient and determined; and will have 
a high level of self-confidence and high internal controls. According to the results of this study, the teachers in the inclusive education usually focused on activity-based education (Turkey, Czech Republic, Italy), while teachers in Germany gave priority to individual approaches to meet the needs of students. At the same time, it was found that the teachers in Germany also included group activities for socializing students. Meeting their needs at various physical, mental and psychosocial levels with different activities is considered as an important factor in contributing to the development areas of students (Robinson, Shore \& Enersen, 2014). The use of appropriate instructional material, structuring the learning environment in accordance with the needs of the student, behavior management and the provision of extracurricular activities reflect many of the teachers' qualifications in the determination and development of the student's interests and abilities (MONE, 2016). According to Wallace and Maker (2009), classroom activities that systematically develop ideas encourage the differentiation of students by accepting their strengths and weaknesses.

In an inclusive education environment with talented and gifted students, it was observed in this study that teachers delivered educational practices in the direction of primarily changing teaching elements in order to change undesirable behaviors of their students. In this context, although the rates in the countries differed, teachers benefited from educational practices such as applying different teaching methods and techniques, promoting problem solving in different ways, giving responsibilities, making individual and group work, giving real-life examples, using and developing peer mediation (Cross, 2011), individualizing learning, using strategy and prevention program. In addition, teachers took advantage of their communication methods, regulated the classroom atmosphere appropriately, and implemented the evaluation method according to the inclusive education. This finding shows that similar educational practices were included in the development of positive behaviour, as well as changing undesirable behavior. In a similar vein, Ertan Kantos (2013) states that German education system offers practices for individual education. Contrary to other countries, it is observed that teachers in Czech Republic focused on obtaining expert assistance (UNESCO, 2015).

In an inclusive educational environment with talented and gifted students, integration of students with different educational needs and features is one of the important elements. It is observed that teachers in this study primarily adapted the teaching method accordingly. Considering the overall teachers in the countries participating in the study, adapting the teaching method was found to be the most frequently repeated bonding activities. It was followed by the regulation of class climate and other studies. It can be considered to be one of the remarkable results that teachers in this study operated in the aspect of having group activities. It can be said that during group activities, students with different learning characteristics will contribute to the psychosocial and educational development of each other. In addition, the majority of the teachers in this study used interaction-based methods and techniques such as drama, cooperative learning and role playing. This can be regarded as important for the development of the students (Gonen, 1998; Ozdogan, 2000; Akbaba, Saglam \& Kok 2003). According to Sucuoglu, Unsal and Ozokcu (2004) a positive class climate is a classroom where the functioning of the classroom, daily routines, rules, expectations are consistent; social-symbol reinforcement is used and positive behaviour is rewarded. While most of the participants indicated activities such as giving responsibility and giving feedback in the adaptation of the teaching method, teachers in Turkey was observed to organise educational trips. It can be stated that in the mainstreaming (Kargin, 2004) of the students with each other, the teachers often give priority to the environment in which the students can socialize. In Germany and Italy as well as Turkey, students are encouraged to take courses with their peers (Kuz, 2001).

While it was emphasized intensely by teachers in Italy that respecting individual traits by accepting the individual as they are, was one of the most important principles of the inclusive education. In addition to the group interaction of teachers in Germany, students performed accountability practices. For the teachers in Turkey, it can be stated that they were predominantly involved in the applications to provide feedback, which is an important element of the communication process (Basar, 2001; Erden, 2005; Bacanli, 2011).

In terms of the inclusive education, it was observed that teachers included educational practices such as students' bonding with each other, and also teaching methods and classroom climate were arranged in such a way that students' interaction with each other would increase. In addition, the teachers stated in the title of other studies and in the scope of cooperation that is emphasized in the teaching profession (Seferoglu, 2004; Sisman, 2009) to seek expert assistance, in the social emotional development of students by developing an effective language, teachers expressed themselves as a contributing factor in accessing the internal worlds of the students (Peterson, 2006). According to Meijer, Soriano ve Watkins (2003, p. 140), "support is addressed to both pupils and teachers, but the main focus is still on the pupil, even though some of the countries clearly indicate that priority is given to the work with class teachers." The arrangement of the classroom climate, which will contribute to the many developmental areas of the students in the bonding of students with different characteristics, it's a highlighted issue for teachers participating in the study.

\section{Suggestions}

1. In the inclusive education process, differentiated educational environments that allow all students to identify and 
develop the abilities they possess should be created. Teachers and administrators should be provided with training to develop knowledge and application skills related to the inclusive education. In this context, the arrangement of teacher trainings, workshops, seminars and workshop-activities can be considered as appropriate activities.

2. Since the findings reveal that there is not enough room for in-class activities related to liability, training for a variety of educational applications in order to fulfill the responsibilities of the students in an internal controlled manner is recommended. In Germany, the cooperation with the stakeholders and parents was the most repeated view of the teachers. However, in Turkey, no opinions were obtained in this category. Based on the research emphasizing the importance of family involvement and the cooperation with the other stakeholders, it will make sense to include collaborative activities in the educational process. In this regard, activities such as various meetings with school, family and other stakeholders, educational trips and training seminars can be useful in developing co-operation.

3. In Turkey's inclusive educational environments the emphasis is given to the educational adaptations in the development of positive behavior and in the management of undesirable behavior. It is advisable to place educational and guidance practices for the psychosocial development areas of the students.

4. Results suggests that the applications aimed at the development of academic skills in the educational applications for teachers were in the forefront, applications for individual and social emotional development of the students remained in the background. In this context, teachers should include activities for the individual and social emotional development of their students.

\section{Acknowledgements}

This study has been developed and produced from the project numbered "2015-1-TR01-KA201-021420", titled "Strategies for Talented and Gifted Pupils' Teachers" which is accepted within the framework of Turkish European Union Erasmus + Mixed School Education program.

\section{References}

Acıkgoz, K. U. (1992). Cooperative learning: theory, research, practice. Malatya: Ugurel Matbaası.

Acıkgoz, K. U., \& Gungor, A. (2006). Effects of cooperative learning on using reading comprehension strategies and attitudes towards reading. Educational Administration: Theory and Practice, 48, 481-502.

Akbaba, S., Saglam, S., \& Kok, M. (2003). Drama and games in education-teaching. Erzurum: Cemre Ofset.

Akyuz, Y. (2008). History of Turkish education BC 1000-M.S. 2008. Ankara: Pegem Akademi.

Ataman, A. (2003). Sınıf içinde karşılaşılan davranış problemleri ve bunlara karşı geliştirilen önlemler. L. Küçükahmet (Ed.). New approaches in classroom management. Ankara: Nobel.

Ataman, A. (Ed.). (2014). What to know about talented and gifted. Ankara: Vize

Avramidis, E. \& Norwich B. (2002) Teachers' attitudes towards integration / inclusion: a review of the literatüre. European Journal of Special Needs Education, 17(2), 129-147. https://doi.org/10.1080/08856250210129056

Aytacli, B. (2015). Comparative education: Examples from world countries, (pp. 13-36). Ankara: An1.

Bacanli, H. (2011). Psychology of education, (16. Bask1). Ankara: Pegem Akademi.

Barton, L. (2003). Inclusive education and teacher education: A basis of hope or a discourse of delusion. University of London: Institute of Education.

Basar, H. (2001). Classroom management. Ankara: Pegem.

Begeny, J. C., \& Martens, B. K. (2007). Inclusionary education in Italy, a literature review and call for more empirical research. Remedial and Special Education, March 1, 80-94. https://doi.org/10.1177/07419325070280020701

Bogdan, R. C., \& Biklen, S. K. (1992). Qualitative research for education: An introduction to theory and methods (2nd ed.). Needham Heights, MA: Allyn and Bacon.

Buyukozturk, S., Kilic, C. E., Akgun, O. E., Karadeniz, S., \& Demirel, F. (2017). Scientific research methods. Ankara: Pegem A.

Caglar, D. (2004). Ustün zekâlı cocukların ozellikleri. M. R. Sirin, A. Kulaksızoglu ve A. E. Bilgili (Haz.). Selected articles book of gifted children. İstanbul: Cocuk Vakfi Yayınları.

Cakmak, M. (2001). Characteristics shown by gifted children and their teachers in the classrooms. Eğitim ve Bilim, 26(122)(56-66).

Cakmak, M. (2003). Sınıf ortamı ve grup etkileşimi. Leyla Kücükahmet (Ed.). New approaches in classroom management, içinde (pp. 24-41). Ankara: Nobel. 
Candace S. B., \& Sharon, V. (2002). Strategies for teaching students with learning and behavior problems (5th ed.). Boston: Allyn and Bacon, A Pearson Education Company.

Comunian, A. L., \& Gielen, U. P. (2000). Sociomoral reflection and prosocial and antisocial behavior: Two Italian studies. Psychological Reports, 87(1), 161-175. https://doi.org/10.2466/pr0.2000.87.1.161

Cook, B. G., Semmel, M. I., \& Gerber, M. M. (1999). Attitudes of principals and special education teachers toward the Inclusion of students with mild disabilities: Critical differences of opinion. Remedial and Special Education, 20(4), 199-207. https://doi.org/10.1177/074193259902000403

Corbett, J. (1999a) Inclusion and Exclusion: issues for debate. In L. Barton and F. Armstrong (Eds.) Difference and Difficulty: Insights, Issues and Dilemmas. Sheffield: University of Sheffield.

Corbett, J. (1999b). Inclusive education and school culture. International Journal of Inclusive Education, 3(1), 53-61. https://doi.org/10.1080/136031199285183

Cross, T. L. (2011). On the social and emotional lives of gifted children: Understanding and guiding their development (4th ed.). Waco, TX: Prufrock Press

Cummings, C. B. (2000). Winning strategies for classroom management. Alexandria, Virginia USA: Association for Supervision and Curriculum Development.

D'Alessio, S. (2011). (Ed.). Inclusive education in Italy: A critical analysis of the policy of integrazione scolastica. The Netherlands: Sense Publishers.

Daglioglu, H. E. (2014). Erken cocuklukta üstün zekâ/üstün yetenek. A. Ataman (Ed.) What to know about gifted and talented, icinde (ss. 47-81). Ankara: Vize Yayıncilık.

Davasligil, U., \& Leana, M. Z. (2004). Ustun zekâlıların egitimi projesi. I. Türkiye Ustun Yetenekli Cocuklar Kongresi Bildiriler Kitabl, 85-100.

Demirel, O. (2000). Compararive education. Ankara: Pegem.

Duskun, Y. (2016). Türkiye'de ortaöğretimde kapsayıcı ĕgitim durum analizi. İstanbul: İmak Ofset Basım.

Enc, M. (2005). Üstün beyin gücü gelişim ve eğitimleri. Ankara: Gündüz Eğitim ve Yayıncılık.

Erden, M. (2005). Classroom management. İstanbul: Epsilon.

Ertan, K. Z. (2013). Federal Almanya Cumhuriyeti eğitim sistemi. A. Balcı (Ed.). Comparative education. Ankara: Pegem.

Fraenkel, J. R., Wallen, N. E., \& Hyun, H. H. (2012). How to design and evaluate research in education ( $8^{\text {th }}$ ed.). New York, NY: The McGraw-Hill Companies, Inc.

Fraser, B. J., \& Walberg, H. J. (2005). Research on teacher-student relationships and learning environments: Context, retrospect and prospect. International Journal of Educational Research, 43(1-2), 103-109. https://doi.org/10.1016/j.ijer.2006.03.001

Freud, S. (1997). Introduction to psychoanalysis. (Çev. Günsel Koptagel-İlal), İstanbul: Mert.

Gagne, F. (2004). Transforming Gifts into Talents: The DMGT as a Developmental Theory, High Ability Studies, 15(2), 119-147. https://doi.org/10.1080/1359813042000314682

Gonen, M. (1998). Drama methods and practices in child education. Epsilon: İstanbul.

Greger, D., \& Walterova, E. (2007). In pursuit of educational change: the transformation of education in the Czech Republic. E. Walterova and D. Greger (Ed). Orbis Scholae, 1(2), 11-44. https://doi.org/10.14712/23363177.2018.165

Grimes, P. (2013). Considering the continuing development of inclusive teachers: A case study from Bangkok, Thailand. European Journal of Special Needs Education, 28(2), 187-202.

Groppelli, A. (1995). Identifying gifted/talented low s.e.s. students, Rome. Universita di Rome La Sapienza, ERIC, Retrieved from: https://files.eric.ed.gov/fulltext/ED395435.pdf, 02.10.2017

Gur, C. (2017). Gifted children with an educational and social-emotional glance. Ankara: An1.

Havel, J., \& Kratochvílová, J. (2014). Maximum expectation from pupils - one of the characteristic features of Inclusion. Procedia - Social and Behavioral Sciences, 141, 331-336. https://doi.org/10.1016/j.sbspro.2014.05.057

Janowski, A. (2007). Educational restructuring and change: Post-communist educational transformation in Poland. E. Walterova and D. Greger (Ed.). Orbis Scholae, 1(2), 80-109. https://doi.org/10.14712/23363177.2018.167 
Kargin, T. (2004). Inclusion: Definition, development and principles. Ankara Üniversitesi Eğitim Bilimleri Fakültesi Özel Eğtim Dergisi, 5(2), 1-13.

Kilicci, Y. (2006). Mental health at school, (Beşinci Bask1). Ankara: Anı.

Kincal, R. Y. (2006). Introduction to educational science. Ankara: Nobel.

Kratochvílová, J., \& Havel, J. (2014). Terms of inclusive education in primary schools-National and school curriculum, Procedia-Social and Behavioral Sciences, 141, 337-341. https://doi.org/10.1016/j.sbspro.2014.05.058

Kuz, T. (2001). Investigation of attitudes towards inclusion education. Uzmanlık tezi, Ankara: TC, Basbakanlık Ozürlüler Idaresi Baskanlıgı Yayınları 17.

Leana-Tascilar, M. Z., Ozyaprak, M., Gücyeter, S., Kanli, E., \& Camci-Erdogan, S. (2014). Evaluation of perfectionism for gifted and talented chıldren. Hasan Ali Yücel Eğitim Fakültesi Dergisi, 11-1(21), 31-45.

Levent, F. (2011). Ustun yetenekli cocukların hakları el kitabı: Anne baba ve ögretmenler için. I. Türkiye Çocuk Hakları Kongresi. İstanbul: Cocuk Vakfi Yayınları.

Levent, F. (2014). Ustun yetenekli cocukları anlamak: Ustun yetenekli cocuklar sarmalında aile, egitim sistemi ve toplum. Ankara: Nobel Akademik.

Manzano-Garcia, B., \& Fernandez, M. T. (2016). The inclusive education in Europe. Universal Journal of Educational Research, 4(2), 383-391. https://doi.org/10.13189/ujer.2016.040210

Marland, S. P. (1972). Education of the gifted and talented: Report to the congress of the United States by the U. S. Commissioner of Education. Washington: U. S. Government Printing Office.

Meijer, C. J. W. (2001). Inclusive education and effective classroom practices. Odense: European Agency for Development in Special Needs Education.

Meijer, C. J. W., Soriano, V., \& Watkins, A. (2003). Special needs education in Europe: Thematic publication. Odense C Denmark: European Agency for Development in Special Needs Education.

Miles, M. B., \& Huberman, A. M. (1994). Qualitative data analysis: An expanded sourcebook. (2nd Edition). California: SAGE.

Milli Egitim Bakanlıgi-Ministry of Education (MONE). (2016). Inclusive education in Turkey. Retrieved from: http://www.goprince.eu/wp-content/uploads/2016/11/INCLUSIVE-EDUCATION-IN-TURKEY.pdf 18.10.2017.

Mitchell, D. (2015). Inclusive education is a multi-faceted concept, Center for Educational Policy Studies (CEPS) Journal 5(1), 9-30.

Nilsen, T., Gustafsson, J. E., \& Blömeke, S. (2016). Conceptual framework and methodology of this report. In T. Nilsen and J. E. Gustafsson (Eds.). Teacher quality, instructional quality and student outcomes: Relationships across countries, cohorts and time (pp. 1-19). Switzerland: IEA Research for Education \& Springer Open. https://doi.org/10.1007/978-3-319-41252-8_1

Ozbay, Y., \& Palanci, M. (2011). Psychosocial characteristics of gifted children and adolecents. The Journal of SAU Education Faculty, 22, 89-108.

Ozdemir, I. E. (2004). Sınıf ortamında istenmeyen davranışlar. S. S. Ercetin ve M. C. Ozdemir (Ed.). Classroom management. Ankara: Asil.

Ozdogan, B. (2000). Kids and games. Ankara: An1.

Patton, M. Q. (2002). Qualitative research and evaluation methods (3rd Edition). Thousand Oaks, CA: Sage.

Peters, S. J. (2003). Inclusive education: Achieving education for all by including those with disabilities and special education needs. Washington, DC: World http://documents.worldbank.org/curated/en/614161468325299263/Inclusive-education-achieving-education-for-all -by-including-those-with-disabilities-and-special-education-needs.

Peterson, J. S. (2006). Addressing Counseling Needs of Gifted Students. ASCA Professional School Counseling, 43-51. https://doi.org/10.5330/prsc.10.1.b76h32717q632tqn

Reid, E., \& Boettger, H. (2015). Gifted education in various countries of Europe. Slavonic Pedagogical Studies Journal, 4(2), 158-171. https://doi.org/10.18355/PG.2015.4.2.158-171

Reis, S. M., \& Renzulli, J. S. (2004). Current Research on the Social and Emotional Development of Gifted and Talented Students: Good News and Future Possibilities, Psychology in the Schools, 4l(1), 119-130. https://doi.org/10.1002/pits.10144 
Robinson, A., Shore, B. M., \& Enersen, D. L. (2014). Ustun zekâlılar egitiminde en iyi uygulamalar [Best practices in gifted education]. Ankara: Nobel.

Rombo, J. L. (2006). Inclusive education: Policies, teachers' attitudes and perspectives, Contemporary PNG Studies: DWU Research Journal 5, Availability: http://search.informit.com.au/documentSummary;dn=085434729233723;res=IELIND> ISSN: 1814-0351

Saban, A. (2002). Learning teaching process, Ankara: Nobel.

Sak, U. (2008). Gifted chilldren. I. H. Diken (Ed.), Ankara: Pegem.

Sak, U. (2015). Ustun zekali ögrencilerin egitimi. İ. H. Diken (Ed.). Ozel egitime gereksinimi olan ögrenciler ve özel egitim icinde (pp. 497-535). Ankara: Pegem Akademi.

Sak, U., Ayas, M. B., Bal Sezerel, B., Opengin, E., Ozdemir, N. N., \& Demirel, G. S. (2015). Gifted and Talented Education in Turkey: Critics and Prospects. Turkish Journal of Giftedness \&Education, 5(2), 110-132.

Seferoglu, S. S. (2004). Teacher competencies and professional development. Bilimin ve Aklın Aydınlı̆̆ında Eğitim, 58, 40-45.

Sisman, M. (2009). Teacher competences: Modern discourse and rhetoric. Inonu University Journal of Education Faculty, Special Issue, 10(3), 63-82.

Sucuoglu, B., Unsal, P., \& Ozokcu, O. (2004). To evaluate proactive classroom managament skills of the teachers working in the inclusive classrooms. Ankara University Faculty of Educational Sciences Journal of Special Education, 5(2), 51-64.

Tortop, H. S. (2015). Differentiated curriculum differentiation models in gifted education, (Birinci baskı). Düzce: Genç Bilge Yayınc1lik.

United Nations Children's Fund (UNICEF). (2014). Teachers, inclusive, child-centred teaching and pedagogy-Webinar 12 - Companion technical booklet. Australian Aid.

United Nations Educational, Scientific and Cultural Organization (UNESCO). (2015). Education for All 2015 National Review Report: Czech Republic. Accessed from http://unesdoc.unesco.org/images/0022/002299/229931E.pdf on 24.12.2017.

Wallace, B., \& Maker, C. J. (2009). DISCOVER/TASC: An approach to teaching and learning that is inclusive yet maximises opportunities for differentiation according to pupils' needs. L. V. Shavinina (Ed.). International Handbook on Giftedness (pp. 1113-1141). Gatineau, Quebec, J8X 3X7, Canada: Springer.

Webb, J. T., Gore, J. L., Amend, E. R., \& DeVries, A. R. (2016). Gifted children (Çev. Bahar Uyaroğlu ve Burcu Bülbün Akt1), Ankara: Anı.

Yalom, I. (2000). Existential psychotherapy. İstanbul: Kabalc1.

Yesilyaprak, B. (2012). Educational psychology: Development-learning-teaching. Ankara: Pegem Akademi.

Yildirim, A., \& Simsek, H. (2016). Qualitative research methods in the social sciences, (10. Bask1). Ankara: Seckin.

Yilmaz, K. (2013). Education system of Italy. A. Balcı (Ed.). Comparative education. Ankara: Pegem.

\section{Copyrights}

Copyright for this article is retained by the author(s), with first publication rights granted to the journal.

This is an open-access article distributed under the terms and conditions of the Creative Commons Attribution license which permits unrestricted use, distribution, and reproduction in any medium, provided the original work is properly cited. 